\title{
Legal Sosio Approach in the Sustainable Utilization of Northern Coastal Area of Jakarta Untoro, Raihan, and Bambang Sukamto
}

Faculty of Law Islamic University of Jakarta

\section{Abstract}

Utilization of the northern coastal area of Jakarta through reclamation is in order to expand the land. Considering the current development of the city of Jakarta, it needs a reclamation program. If you want to see more clearly about reclamation, you should see between the policy of reclamation and the implementation of reclamation policy on the north coastal of Jakarta. It means, it cannot be separated from the social and personal forces that encompass it. The method used in this research was a normative juridical research with a socio-legal approach. This study tried to approach a problem of the reclamation in the North Coastal of Jakarta by combining between normative analysis

Corresponding Author:

Untoro

untoro_uid@yahoo.co.id

Received: 18 January 2019

Accepted: 24 March 2019

Published: 31 March 2019

Publishing services provided by

Knowledge E

(c) Untoro et al. This article is

distributed under the terms of

the Creative Commons

Attribution License, which

permits unrestricted use and

redistribution provided that the

original author and source are

credited.

Selection and Peer-review unde the responsibility of the First ELEHIC Conference Committee.

\section{G OPEN ACCESS} and non-legal science approach through the study of non-legal theory. The purpose of this study was to find out how legal products can be the basis in the sustainable use of coastal areas. Consequently, the legal products that become the foundation in the utilization of coastal areas contain the meaning of the values of alignment to the interests of the environment. The formulation of the problem is why the reclamation of North Coastal Jakarta got rejection from the traditional fishermen in MuaraAngke? How is the policy of Jakarta Capital City in reclamation of North Coastalarea of Jakarta linked to the concept of sustainable development?

Keywords: socio legal, coastal, sustainable utilization.

\section{Introduction}

Jakarta is as a city in the delta area traversed by 13 river flows and influenced by the tidal stream, then in developing the city of Jakarta, we should consider the challenges and constraints in delta are that can be done through water management, disaster risk analysis, and ecosystem improvement. The delta city is a city located at the mouth of a river or river estuary, it makes some of the areas are under the sea level. Furthermore, with the existence of climate change, it will be increasingly threatened.

The North Coastal area of Jakarta is designated as a Strategic Area of DKI Jakarta Province set forth in Regional Regulation No. 1 of 2012 on Spatial Planning (RTRW) 
Jakarta 2030. The stipulation is in line with other policies namely Government Regulation No. 26 of 2008 on National Spatial Planning. With this Government Regulation, DKI Jakarta with the surrounding area that characterizes the Metropolitan area is designated as a National Strategic Area. The status of DKI Jakarta and the surrounding area as a National Strategic Area shall be further regulated in spatial planning through Presidential Regulation No. 54/2008 concerning Spatial Planning in Jakarta, Bogor, Depok, Tangerang, Bekasi, Puncak and Cianjur (Jabodetabekpunjur).

In strategic North Coastal area of Jakarta, the development of reclamation area and coastal land area is done in an integrated manner which together is designated as a planning area. There are many interests to consider in the implementation of reclamation. It must consider the environment, the interests of the harbor, the interests of mangrove forest areas, the interests of fishermen, the impact of the rob flood, and the rise of sea and river levels as well as interests and other functions in the North Coast of Jakarta.

Due to limited land in Jakarta Capital Special Region (DKI), the reclamation in North Coastalarea of Jakarta is directed to the realization of reclaimed land ready to build and its utilization in accordance with the integrated spatial planning with the re-arrangement of North Jakarta's mainland area. Taking into account the guidelines derived from the legislation in the field of reclamation, it is expected that reclamations run in accordance with the philosophy of reclamation, that is, the first reclamation is an alternative activity to get land for various designations so that fertile agricultural land and rainwater absorption area is not sacrificed by the needs of the expansion of the city. Second, reclamation must follow applicable regulations such as coastal law, Presidential Regulation, general guidelines of reclamation, and reclamation technical guidelines. Third, reclamation can be implemented if negative impacts can be eliminated. Fourth, to avoid damage to buildings on reclamation land, reclamation must meet the technical requirements of reclamation [1].

Reality in the implementation of reclamation in the North Coastal area of Jakarta encountered many obstacles. Reclamation of the north coast of Jakarta in order to realize 17 islands with the name of Island are $A, B, C, D, E, F, G ~ H, I, J, K, L, M, N, O, P, Q$. The extent reaches 5,153 hectares and requires about 3.3 Million tons of cubic meters of sand for swelling. The sand is taken from the sea around Serang Banten, which is around Pulau Tunda and Pulau Panjang. All sand dredging location is suspected not through the study of Environmental Impact Analysis (EIA). So the dredging of the sand under the sea gives a bad impact to the coast around Serang Banten. [2].

Fishermen in the coastal areas of North Jakarta coast adjacent to the reclamation site are also disrupted by reclamation. They postulate reclamation resulting in access 
to disturbed fish. This has meant problems in the organization of spatial planning, two factors that determine the population density and economic growth [3].

Based on the background above, there are several problem formulations in this study, namely: Why the reclamation of North Coastal Area of Jakarta get rejection from Muara Angke traditional fishermen? How is the policy of Jakarta Capital City Special Government in reclamation of North Coastal area of Jakarta associated with sustainable development concept?

\section{Research Methodology}

The research method used in this study was normative juridical method because the study was based on the sustainability of the socio-legal approach. Considering that the problem of North Jakarta coastal area reclamation cannot be done through a partial approach, but must be done through an integrated, comprehensive, and holistic approach. Hence, the problem of reclamation cannot be solved by mono-discipline study, but must be through a multi-disciplinary settlement. An important characteristic of socio-legal studies is in the nature of the study, it uses multi or interdisciplinary. In other words, theoretical perspectives and methodologies are based on research conducted with various disciplines [4]. The legal materials were collected through literature studies. On the other hand, the research analysis was done descriptive qualitatively, it means the legal materials were described in the form of narrative arranged in a systematic, logical, and it was the result of the process of interpretation of researchers on the legal material produced.

\section{Discussion}

\subsection{Rejection of traditional fishermen of Muara Angke on reclamation in North Coastal Area, Jakarta}

Traditional fishermen of Muara Angke are one of the stakeholders in the coastal area of North Coastal Area of Jakarta. Because of the number of fish catches in the coastal area became reduced after the construction of islands through reclamation. Fishermen in Muara Angke, the owners have boats with sizes above 10 gross tons and below 10 gross tons, boats with sizes below 10 gross tons are owned by traditional fishermen who are unlikely to catch fish far to the sea due to the threat of waves. To be able to catch the fish with a distance of more than 4 miles from the shoreline, they require ships 
with a minimum capacity of 30 gross tons. In addition to the issue of fish catches for the traditional fishermen, the thing to note is also related to the existence of mangrove forests, because the reclamation will disrupt the existence of mangrove forests.

The rejection of fishermen against reclamation is followed up by filing a lawsuit to the Jakarta State Administrative Court. The arguments used by fishermen in their lawsuit state that the reclamation license is contradictory to Article 33 Paragraph (3) of the 1945 Constitution of the State of the Republic of Indonesia (3) of the 1945 Constitution of the State of the Republic of Indonesia, it has been interpreted by the Constitutional Court in the Decision of the Constitutional Court Number 3/PUU-VIII/2010. The interpretation of the phrase "Earth, water and wealth contained therein is controlled by the state": There are four powers and freedoms owned by the State, namely:

1. State is given authorities and freedom to organize.

2. State is given authorities and freedom to make policy.

3. State is given authorities and freedom to manage.

4. State is given authorities and freedom to supervise.

Interpretation is also given by the Constitutional Court on the phrase "For the greatest prosperity of the people", contained four benchmarks that can be used as a test stone in assessing the freedom to regulate and make policy whether it has been intended for the greatest prosperity of the people, namely:

1. Utilization of natural resources for the people.

2. The level of equitable distribution of natural resources for the people.

3. The level of people's participation in determining the benefits of natural resources.

4. Respect for the right of the people inherited in the utilization of natural resources.

Refusal by fishermen in the North Coastal Area of Jakarta to reclamation activity led to a conflict between the Governor of DKI Jakarta as a defendant. According to the theory of social conflict, sociologically the study of conflict is part of the social process. In the social process that becomes the object of observation is a social event or social action that has the nature of closer or associative and distancing or dis-associative [5]. So in this context, reclamation is a social event that has the nature of distancing-with the conflict. The examples of social actions that have a closer nature is cooperation. Cooperation belongs to the associative group, in cooperation there is interaction between several 
people with common goals. On the other hand, the conflict belongs to social actions that have the nature of distancing, while that belongs to the nature of distancing is conflict. Thus, cooperation can be a solution to mitigate conflict in North Jakarta coastal reclamation. Meanwhile, in view of Gramsci hegemony theory, what needs to be done in the reclamation is to minimize the resistance of fishermen and at the same time the Central Government and the Special Capital City Government of Jakarta should create spontaneous adherence from North Jakarta coastal fishermen. So it takes cooperation between the Government of the Special Capital Region of Jakarta, Developers and Fishermen in the North Coastal Area of Jakarta.

\subsection{The policy of the special capital city government of Jakarta in the reclamation of the North Coastal of Jakarta is linked to the concept of sustainable development}

Law Number 26 Year 2997 on Spatial Planning does not mention the reclaimed land, as well as in Law No. 24 of 1992 on Spatial Planning that no longer applies. The provisions on reclamation during the enactment of Law Number 24 of 1992 are contained in several regulations under the law.

The reclamation of the North coastal of Jakarta which is part of the coastal area utilization raises the conflict of interest and the social impact on the environment. This conflict of interest should be eliminated by applying a comprehensive policy in the form of marine spatial as well as national agrarian resource policy[6].Reclamation of the north coastal area of Jakarta is to realize 17 artificial islands, namely island $A$ to island $Q$ with nine developers in the reclamation activities, namely Limited Company (PT): Muara Wisesa Samudra, Pelindo II, Manggala Krida Yudha, Taman Harapan Indah, Jaladri Kartika Ekapaksi, Jakarta Propertindo, Pembangunan Jaya Ancol, Kapuk Naga Indah. Implementation of North Jakarta beach reclamation in relation to the concept of sustainable development[7], namely:

1. The ongoing development process is supported by sustainable natural resources, environmental and human qualities;

2. Natural resources such as land, water, air have a threshold in which their use will decrease quantity and quality, so that it will reduce the support of continuous development and cause disturbance to the harmony of natural resources and human resources.

3. The quality of the environment has a direct relationship with the quality of life. 
4. Development enables the present generation to improve their welfare without diminishing the possibility of future generations to improve its well-being.

Sustainable development in addition to have a concept also has sustainability goals to be achieved[8]. The sustainability objectives to be achieved by this sustainable development can be used as a test stone against the reclamation of the north coastal of Jakarta. The sustainability objectives to be achieved are: Ecological sustainability; Economic sustainability; Socio-cultural sustainability; Political sustainability; Sustainability of defense and security.

Ecological sustainability is a prerequisite not only aimed at development, but also for the sustainability of life. In other words, even there is no development, ecological sustainability remains required. Some things that must be done to maintain ecological sustainability, namely: maintaining and sustaining the integrity of the environment (ecosystem) order for life support systems in advance is guaranteed; maintaining and sustaining biodiversity in the diversity of life in which ecological processes depend on sustainability.

Economic sustainability in development perspectives has two main things, namely macroeconomic sustainability and sectorial economic sustainability. These two economic sustainability have a close relationship with the objectives of sustainability of other aspects. Three important elements are necessary for macroeconomic sustainability, namely economic efficiency, economic welfare sustainable, improving equity and distribution of prosperity. Sectorial economic sustainability is useful for improving matters relating to policy adjustments to improve short-term macroeconomic sustainability, because if not corrected it will lead to sectorial distortions that will further neglect ecological sustainability. Therefore, it must be corrected through sector-specific and specific policies.

Socio-cultural sustainability is thoroughly expressed in sentences: social justice, human dignity and the improvement of the quality of life of all human beings. Goals to be achieved in social and cultural sustainability, namely: population stability; meet basic human needs; maintaining cultural diversity; encouraging local community participation in decision making.

The concept of sustainable development emphasizes the implementation of development today, it is not only to meet the needs of today's generation alone, but also must pay attention to future generations. In sustainable development requires a fundamental change from the conventional development paradigm. There are three fundamental changes [9]. First, sustainable development changes the short-term perspective into a 
long-term development perspective. Conventional development usually pursues shortterm profits by exploiting natural resources. Secondly, sustainable development weakens the dominant position of the economic aspect and places it at the same level as social and environmental development. In this connection, the increase in the number of population has led to various social development issues that become obstacles to the benefits of economic growth. Increased population causes additional land needs to meet food, work, infrastructure and housing needs. Third, the scale of individual preferences becomes the indicator that determines what goods will be produced and through the method of resource allocation as efficiently as possible. The demand for goods by particular individuals is supported by high income and purchasing power. The interest is ultimately more powerful than the public interest. Sustainable development requires a fundamental change of policy so that there is no private interest in the public interest.

The policy that become the legal basis for reclamation in the coastal area of North Jakarta is Presidential Decree Number 52 Year 1995 concerning Reclamation of North Coastal of Jakarta, Regional Regulation of the Special Capital Region of Jakarta Number 8 Year 1995 concerning the Reclamation and Spatial Plan of North Jakarta Coastal Area; Regulation of the Special Capital Region of Jakarta No. 1 of 2012 on Spatial Planning of 2030; Presidential Regulation No. 54/2008 on Spatial Planning of Jakarta, Bogor, Depok, Tangerang, Bekasi, Puncak, and Cianjur Governor Regulation No. 121 of 2012 on Spatial Planning of the North Jakarta Coastal Reclamation Area; Presidential Regulation No. 122/2012 on Reclamation in Coastal Areas and Small Islands.

Presidential Decree Number 52 of 1995 on Reclamation of North Beach Jakarta is the first legal basis for reclamation on the North Coastal area of Jakarta. The definition of reclamation is declared to be a hoarding and draining activity in marine waters. Reklamasi in English is called reclamation, from the angle of the word, it is the process of reclaiming something from loss or from a less useful condition that is the process of recovering something from loss or a state less useful. This reclamation understanding has not been concretely related to something that will be recovered, because in the sense of reclamation is still general. Cambridge Advanced Learner's Dictionary provides an understanding of reclamation, first: experiments to make land suitable for buildings or agriculture. Second is the processing of waste materials to obtain useful materials from it [10]. Observing the definition of reclamation above, from the definition of reclamation has become the concept of North Jakarta coastal reclamation.

The provisions related to spatial arrangement in Presidential Decree No. 52 of 1995 on North Coast Reclamation of Jakarta are declared no longer valid. This is in 
line with the issuance of Presidential Regulation No. 54 of 2008 on Spatial Planning Jabodetabekpunjur Area. Article 70 affirms that Presidential Decree Number 52 Year 1995 remains valid as long as it is not contradictory and has not been replaced by the new implementation regulation in accordance with this Presidential Regulation. Several other provisions relating to the reclamation of the North Coast of Jakarta are contained in Article 34, Article 42, Article 45, Article 48.

The Regional Regulation of the Special Capital Region of Jakarta Number 8 of 1995 on the Implementation of Reclamation and Spatial Planning of the North Coastal of Jakarta states about the principle of the reclamation and spatial arrangement of the North area of Jakarta that is the utilization of space for all interests in an integrated, efficient and effective, harmonious, aligned, balanced and sustainable. Therefore, the effectiveness of applied policy is one of the key successes of North Jakarta coastal area development. So the development of North Coastal area development policy needs to involve various parties namely Central Government, Local Government of DKI Jakarta, entrepreneur, local community including fisherman, non-governmental organization [11].

The principle of reclamation and spatial arrangement of the north coastal of Jakarta requires the utilization of space for all interests. The utilization of space for all is done in an integrated, efficient and effective, harmonious, balanced and sustainable manner indicates that there is a wide range of interests that must be met for every stakeholder in the northern coastal area of Jakarta.

The concept of sustainable development as mentioned above in the context of the northern coastal reclamation of Jakarta has not shown ecological sustainability; economic sustainability; socio-cultural sustainability. The same is also conveyed from previous researchers who stated that the development of North coastal area of Jakarta has not reached the condition of sustainability. Unsustainable dimensions are ecological, economic, social, and technological [12].

\section{Conclusion}

1. Rejection or resistance of fishermen to reclamation of North Coastal area of Jakarta by filing a lawsuit to the State Administrative Court showed an injustice on the side of traditional fishermen of Muara Angke, North Jakarta. Injustice occurs because of disruption of access to fish in the coastal area of North Beach Jakarta. According to the theory of social conflict, sociologically the study of conflict is part of the social process. In view of the theory of social conflict, reclamation is a social process that becomes the object of observation that has the nature of distancing-conflict. 
The solution offered is cooperation. Where cooperation belongs to the associative group, in cooperation there is interaction between several people with based on common goals.

2. The reclamation of the North coastal of Jakarta which is part of the coastal utilization leads to conflict of interest and environmental social impacts. This conflict of interest should be eliminated by applying a comprehensive policy in the form of marine spatial as well as national agrarian resource policy.

\section{References}

[1] Nizam.(2003) Dalam Direktorat Jenderal Kelautan Pesisir, Dan Pulau-Pulau Kecil Departemen Kelautan Dan Perikanan. Kriteria, Prinsip Dasar Dan Mekanisme Perizinan Dalam Pelaksanaan Reklamasi Wilayah Pesisir..

[2] Michael, David. Maasvlakte 2.Suatu Pembelajaran tentang Reklamasi.

[3] Untoro. (2012). Hukum Tata Ruang dan Hukum Lingkungan. Dalam Upaya Menjaga Kelestarian Lingkungan. Jakarta: Universitas Islam Jakarta.

[4] Satria, Arif. (2015). Pengantar Sosiologi Masyarakat Pesisir. Jakarta. Yayasan Pustaka Obor Indonesia.

[5] Satria, Arif. (2015). Politik Kelautan Dan Perikanan. Jakarta. Yayasan Pustaka Obor Indonesia.

[6] Flora Pricilla Kalalo,(2009).Implikasi Hukum Kebijakan Reklamasi Pantai \& Laut di Indonesia Buku I. Cetakan Kesatu.Cetakan Kesatu. Tanpa kota penerbit: Logoz Publishing.

[7] Raihan.(2013). Lingkungan \& Hukum Lingkungan.Edisi Kedua CetakanV.Jakarta: Universitas Islam Jakarta..

[8] Raihan.(2013). Lingkungan \& Hukum Lingkungan.Edisi Kedua CetakanV.Jakarta: Universitas Islam Jakarta..

[9] EndangSutrisno. (2016) Rekonstruksi kebijakan Lingkungan berbasis Nilai Kearifan Lokal. Dalam Penelitian Hukum Interdisipliner. Sebuah Pengantar Menuju SosioLegal. CetakanI.Yogyakarta: Thafa Media

[10] Flora Pricilla Kalalo, (2009).Implikasi Hukum Kebijakan Reklamasi Pantai \& Laut di Indonesia Bukull.Cetakan Kesatu. Tanpa kota penerbit: Logoz Publishing

[11] Supono, Sapto. (2009)..Disertasi. Model Kebijakan Pengembangan Kawasan Pantai Utara Jakarta Secara Berkelanjutan. Sekolah Pascasarjana. Institut Pertanian Bogor. 
[12] Supono, Sapto. (2009)..Disertasi. Model Kebijakan Pengembangan Kawasan Pantai Utara Jakarta Secara Berkelanjutan. Sekolah Pascasarjana. Institut Pertanian Bogor. 